\title{
Endocrine and metabolic response in the human newborn to first feed of breast milk
}

\author{
A. AYNSLEY-GREEN, S. R. BLOOM, D. H. WILliAMSON, AND R. C. TURNER \\ From the University Department of Paediatrics, John Radcliffe Hospital, Oxford; the Royal Postgraduate \\ Medical School, Hammersmith Hospital, London; and the Metabolic Research Laboratory, Nuffield \\ Department of Clinical Medicine, Radcliffe Infirmary, Oxford
}

SUMMARY The hormonal and metabolic response to the first feed of breast milk was studied in 12 infants at 4-6 hours of age. After the feed there was an increase in blood glucose concentration but no changes in the concentrations of lactate, pyruvate, alanine, or ketone bodies. The feed was followed by an increase in the concentrations of plasma insulin, growth hormone, gastrin, and enteroglucagon, but no change in levels of plasma glucagon or gastric inhibitory peptide. Several hormone systems are functionally active at birth and are stimulated by the first feed of milk.

At birth the continuous supply of nutrients which the fetus received across the placenta is interrupted and the neonate has to adapt to a new environment of intermittent feeding and fasting. There is evidence that changes in plasma hormone concentrations after birth are responsible for some of the changes in hepatic enzyme activity which occur during the period of metabolic adaptation (Shelley et al., 1975). Animal studies have shown that postnatal feeding modulates the development of glucose-stimulated insulin secretion (Gentz et al., 1971; Asplund, 1972). However, the effect of feeding on gastrointestinal and pancreatic insular hormone secretion and their relationship to circulating blood metabolite concentrations have not been studied in the human newborn.

We report measurements of the blood levels of several hormones and metabolites before and after the first feed of expressed breast milk in a group of infants suffering from moderately severe respiratory distress.

\section{Patients and methods}

Twelve infants were studied with the approval of the Ethical Committee. All had been admitted to the special care baby unit, and all had indwelling umbilical arterial catheters for clinical monitoring purposes. They were nursed in infant incubators at an environmental temperature appropriate for their weight and gestation (Hey and Katz, 1970). None had a rectal temperature lower than $36^{\circ} \mathrm{C}$ at the time

Received 27 July 1976 of the study. The mean birthweight was $2945 \mathrm{~g}$ (range 2110-3940 g) and mean gestational age $37 \cdot 8$ weeks (range 37-39 weeks). 9 infants were suffering from moderately severe respiratory distress requiring enriched inspired oxygen concentrations. Of the other 3 , one was a breech delivery with severe birth asphyxia and 2 had lesser degrees of birth asphyxia requiring transient endotracheal intubation, oxygen, and alkali therapy. None had an arterial $p \mathrm{H}<7 \cdot 25$, and the inspired oxygen concentration was adjusted to maintain the $\mathrm{PaO}_{2}$ in the range 60-90 torr. No change in inspired oxygen concentration was required during the study period and the clinical condition of the infants did not change.

Feeding procedure. The first feed was given between 4 and 6 hours of age. Nasogastric tubes were inserted and the stomach contents aspirated $\mathbf{3 0}$ minutes before the feed. When the contents were copious, tenacious, or heavily stained with meconium $5-10 \mathrm{ml}$ of $0.9 \%$ saline at $37^{\circ} \mathrm{C}$ were used to irrigate the stomach, the contents being reaspirated. The infants were then given $5 \mathrm{ml} / \mathrm{kg}$ pooled mature expressed breast milk (EBM), which is the volume needed to give $60 \mathrm{ml} / \mathrm{kg}$ per $24 \mathrm{~h}$ with a 2-hourly feeding regimen. The feed was given by gravity over 2-4 minutes, the infant lying on the right side with the head of the mattress raised. The infants were not disturbed during the study period. At the end of the test the stomach contents were reaspirated and in no case was more than $25 \%$ of the original feed volume returned. Regurgitation of the feed did not occur in any instance. 
Blood sampling. Blood samples, each of 1.0-1.4 ml, were drawn from the aorta via the umbilical artery catheter immediately before the feed and at 5, 25, and 55 minutes after the feed. Immediately on withdrawing, blood $(0.4 \mathrm{ml})$ was added to $4 \mathrm{ml}$ ice-cold $5 \%$ perchloric acid for the assay of metabolites; $0 \cdot 1-0 \cdot 2 \mathrm{ml}$ blood was added to a heparinized tube for insulin and growth hormone assay; $0.5-0.9 \mathrm{ml}$ blood was added to $0.1 \mathrm{ml}$ aprotinin (Trasylol $1000 \mathrm{KlU}$ ) containing $50 \mathrm{mmol}$ EDTA for the assay of the other hormones.

Assay methods. Concentrations of glucose, lactate, pyruvate, alanine, acetoacetate, and $\beta$-hydroxybutyrate in whole blood were determined enzymatically (Bergmeyer, 1963). Plasma gastrin was measured by a radioimmunoassay using an antiserum raised against synthetic human gastrin 1 which measured big gastrin (G34) and little gastrin (G17) equally, but which did not react significantly with big big gastrin, little little gastrin (G14), or cholecystokinin pancreozymin. Standards (MRC 68-439) were made up in gastrin-free plasma and individual differences of $2.5 \mathrm{pmol} / 1$ plasma could be detected with $95 \%$ confidence. Plasma $\mathrm{N}$-terminal reactive glucagon-like immunoreactivity (enteroglucagon, or intestinal glucagon) and plasma C-terminal reactive glucagon-like immunoreactivity (pancreatic glucagon) were measured as described previously (Bloom, 1974). Plasma gastric-inhibitory peptide (GIP) was measured by conventional radioimmunoassay techniques using an antiserum raised to pure natural porcine GIP and pure porcine GIP standards. Changes of $10 \mathrm{pmol} / 1$ plasma could be detected with $95 \%$ confidence. Plasma insulin was measured using charcoal phase separation (Albano et al., 1972) with simultaneous growth hormone assay (Turner et al., 1971). The precision ( $\pm 1 \mathrm{SD})$ was $1.4 \mathrm{mU} / 1$ plasma insulin, and $1 \cdot 5 \mu \mathrm{g} / 1$ plasma growth hormone. Results were assessed for statistical significance by means of the Student's ' $t$ ' test.
Results

Blood glucose and other metabolites. The mean ( \pm SEM) fasting blood glucose concentration was $3.67 \pm 0.22 \mathrm{mmol} / 1 \quad(66 \cdot 12 \pm 3.96 \mathrm{mg} / 100 \mathrm{ml})$ a significant rise occurred after the feed, the mean increment at 55 minutes being $0.84 \mathrm{mmol} / \mathrm{l}(15$ $\mathrm{mg} / 100 \mathrm{ml}$ ) (Fig. 1).

The mean fasting blood lactate and pyruvate concentrations were $2 \cdot 37 \pm 0 \cdot 71 \mathrm{mmol} / 1(21 \cdot 33 \pm$ $6.4 \mathrm{mg} / 100 \mathrm{ml})$ and $195 \pm 42 \mu \mathrm{mol} / 1(1 \cdot 7 \pm 0 \cdot 4$ $\mathrm{mg} / 100 \mathrm{ml}$ ) respectively (Table 1 ); no significant change occurred after the feed (Table 1). Mean basal blood alanine $(0 \cdot 37 \pm 0 \cdot 10 \mathrm{mmol} / \mathrm{l})$ concentration did not change significantly after the feed (Table 1).

Basal blood acetoacetate and $\beta$-hydroxybutyrate concentrations were $0.132 \pm 0.022$ and $0.122 \pm$ $0.024 \mathrm{mmol} / \mathrm{l}$ respectively. No significant change in the concentration of either occurred as a result of feeding (Table 1) and the $\beta$-hydroxybutyrate: acetoacetate ratio remained constant.

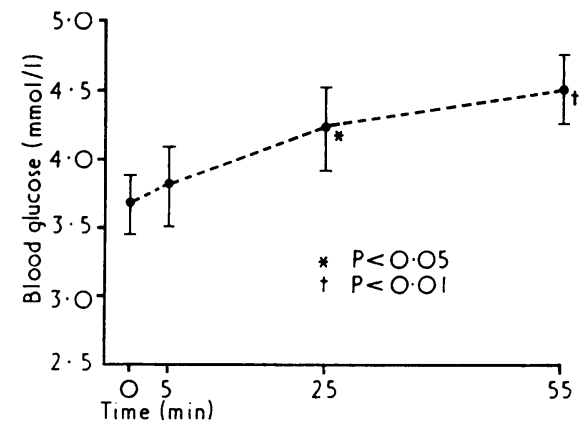

Fig. 1 Effect of first feed of expressed breast milk on blood glucose concentration $(n=12)( \pm S E M)$.

Conversion: SI to traditional units-Glucose: 1 $\mathrm{mmol} / \mathrm{l} \approx 18 \mathrm{mg} / 100 \mathrm{ml}$.

Table 1 Metabolite concentrations in arterial blood before and after the first feed of expressed breast milk $(5 \mathrm{ml} / \mathrm{kg})( \pm S E M, n=12)$

\begin{tabular}{|c|c|c|c|c|}
\hline & \multicolumn{4}{|l|}{ Time (min) } \\
\hline & 0 & 5 & 25 & 55 \\
\hline $\begin{array}{l}\text { Lactate }(\mathrm{mmol} / \mathrm{l}) \\
\text { Pyruvate }(\mu \mathrm{mol} / \mathrm{l}) \\
\text { Lactate/pyruvate ratio } \\
\text { Alanine }(\mathrm{mmol} / \mathrm{l}) \\
\text { Acetoacetate }(\mathrm{mmol} / \mathrm{l}) \\
\beta-H y d r o x y b u t y r a t e(\mathrm{mmol} / \mathrm{l}) \\
\text { Total ketone bodies }(\mathrm{mmol} / \mathrm{l}) \\
\beta-O H-a c e t o a c e t a t e ~ r a t i o\end{array}$ & $\begin{array}{l}2 \cdot 37 \pm 0 \cdot 71 \\
195 \pm 42 \\
11 \cdot 9 \pm 1 \cdot 9 \\
0 \cdot 37 \pm 0 \cdot 10 \\
0 \cdot 132 \pm 0 \cdot 022 \\
0 \cdot 122 \pm 0 \cdot 024 \\
0 \cdot 254 \pm 0 \cdot 040 \\
1 \cdot 0 \pm 0 \cdot 18\end{array}$ & $\begin{array}{l}1 \cdot 73 \pm 0 \cdot 34 \\
170 \pm 22 \\
10 \cdot 2 \pm 1 \cdot 3 \\
0 \cdot 32 \pm 0 \cdot 07 \\
0 \cdot 146 \pm 0 \cdot 036 \\
0 \cdot 133 \pm 0 \cdot 026 \\
0 \cdot 279 \pm 0 \cdot 055 \\
1 \cdot 0 \pm 0 \cdot 20\end{array}$ & $\begin{array}{l}2 \cdot 02 \pm 0 \cdot 43 \\
166 \pm 26 \\
11 \cdot 8 \pm 1 \cdot 1 \\
0 \cdot 32 \pm 0 \cdot 07 \\
0 \cdot 142 \pm 0 \cdot 032 \\
0 \cdot 151 \pm 0 \cdot 026 \\
0 \cdot 293 \pm 0.051 \\
1 \cdot 2 \pm 0 \cdot 19\end{array}$ & $\begin{array}{l}1 \cdot 80 \pm 0 \cdot 31 \\
173 \pm 26 \\
10 \cdot 4 \pm 0 \cdot 8 \\
0 \cdot 33 \pm 0 \cdot 07 \\
0 \cdot 151 \pm 0 \cdot 024 \\
0 \cdot 151 \pm 0 \cdot 030 \\
0 \cdot 302 \pm 0 \cdot 047 \\
1 \cdot 2 \pm 0 \cdot 25\end{array}$ \\
\hline
\end{tabular}

None of the post-feed values differ significantly from the pre-feed value.

Conversion: SI to traditional units-Lactate: $1 \mathrm{mmol} / 1 \approx 9 \mathrm{mg} / 100 \mathrm{ml}$. Pyruvate: $1 \mu \mathrm{mol} / 1 \approx 0.0088 \mathrm{mg} / 100 \mathrm{ml}$. 
Table 2 Plasma growth hormone and gastric inhibitory peptide (GIP) concentrations in arterial blood before and after the first feed of expressed breast milk $(5 \mathrm{ml} / \mathrm{kg})( \pm S E M)$

\begin{tabular}{|c|c|c|c|c|}
\hline & \multicolumn{4}{|l|}{ Time (min) } \\
\hline & 0 & 5 & 25 & 55 \\
\hline $\begin{array}{l}\text { Growth hormone }(\mu \mathrm{g} / \mathrm{l}) \\
\mathbf{n} \\
\mathbf{P}\end{array}$ & $\begin{array}{l}17 \cdot 7 \pm 3 \cdot 2 \\
11\end{array}$ & $\begin{array}{l}16 \cdot 3 \pm 3 \cdot 0 \\
11 \\
\text { NS }\end{array}$ & $\begin{array}{l}13 \cdot 7 \pm 2 \cdot 5 \\
11 \\
\text { NS }\end{array}$ & $\begin{array}{l}27 \cdot 8 \pm 5 \cdot 4 \\
11 \\
<0.05\end{array}$ \\
\hline $\begin{array}{l}\text { GIP }(\mathrm{pmol} / \mathrm{l}) \\
\quad \mathbf{n} \\
\mathbf{P}\end{array}$ & $\begin{array}{l}117 \cdot 7 \pm 31 \cdot 7 \\
8\end{array}$ & $\begin{array}{l}202 \cdot 7 \pm 78 \cdot 6 \\
8 \\
\text { NS }\end{array}$ & $\begin{array}{l}168 \cdot 9 \pm 37 \cdot 9 \\
8 \\
\text { NS }\end{array}$ & $\begin{array}{l}154 \cdot 1 \pm 27 \cdot 8 \\
8 \\
\text { NS }\end{array}$ \\
\hline
\end{tabular}

Plasma hormones. The mean fasting plasma insulin concentration was $6 \cdot 8 \pm 1 \cdot 3 \mathrm{mU} / 1$ and a significant progressive rise occurred after the feed, reaching a mean value of $15 \cdot 3 \pm 3 \cdot 2 \mathrm{mU} / 1$ at 55 minutes (Fig. 2). Mean basal growth hormone level was $17 \cdot 7 \pm 3 \cdot 2 \mu \mathrm{g} / \mathrm{l}$, and a significant increase to a mean value of $27 \cdot 8 \pm 5 \cdot 4 \mu \mathrm{g} / 1$ occurred 55 minutes after the feed (Table 2). Mean basal plasma gastrin concentration was $10 \cdot 9 \pm 1 \cdot 3 \mathrm{pmol} / \mathrm{l}$; after the feed there was an immediate and progressive rise to a mean value of $26 \cdot 1 \pm 1.9 \mathrm{pmol} / \mathrm{l}(\mathrm{P}<0.01)$ at 55 minutes (Fig. 3).

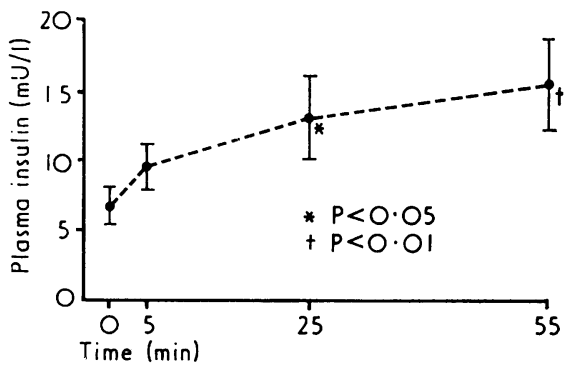

Fig. 2 Effect of first feed of expressed breast milk on plasma insulin $(n=11)( \pm S E M)$.

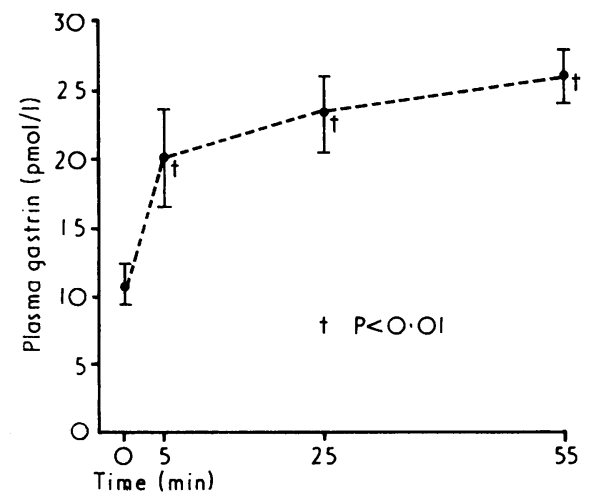

Fig. 3 Effect of first feed of expressed breast milk on plasma gastrin $(n=9)( \pm S E M)$
Mean basal pancreatic glucagon concentration was $65 \cdot 2 \pm 11 \cdot 7 \mathrm{pmol} / \mathrm{l}$, and this did not change significantly after the feed (Fig. 4). In contrast, the mean basal enteroglucagon level was $145 \cdot 0 \pm 30 \cdot 0$ $\mathrm{pmol} / \mathrm{l}$, and a significant rise to $305 \cdot 5 \pm 64 \cdot 8 \mathrm{pmol} / 1$ occurred after 55 minutes (Fig. 4).

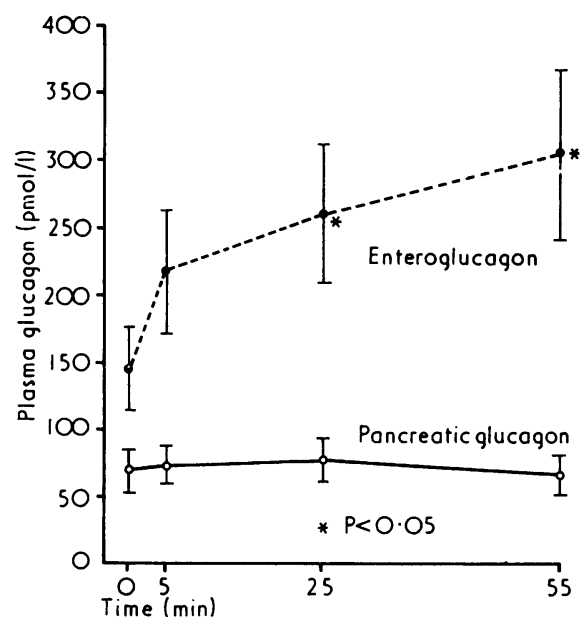

Fig. 4 Effect of first feed of expressed breast milk on plasma glucagon $(n=11)( \pm S E M)$.

Mean plasma GIP concentration before the feed was $117 \cdot 7 \pm 31 \cdot 7 \mathrm{pmol} / \mathrm{l}$, and this did not change after the feed (Table 2).

\section{Discussion}

Although blood glucose concentrations during the first few hours of life have been measured by several investigators there is no previous study on the effect of the first feed of milk on blood glucose levels. Our results show that a feed of $5 \mathrm{ml} / \mathrm{kg}$ of breast milk causes a consistent rise in blood glucose in the order of $15 \mathrm{mg} / 100 \mathrm{ml}$. This finding suggests that the first feed had been at least partially digested and absorbed. In contrast to the rise in glucose after the feed 
no significant change occurred in the concentrations of the other metabolites of carbohydrate metabolism (lactate, pyruvate, or alanine) or in the alternative substrates to glucose (ketone bodies). The absence of a decrease in the levels of ketone bodies is somewhat surprising in view of the rise in insulin concentrations (Fig. 1), which in the adult might be expected to depress lipolysis in adipose tissue and thus lead to a decrease in hepatic ketogenesis.

Most of the infants in this series were suffering from conditions likely to cause hypoxia but, despite this, the mean blood lactate concentrations and the $L / P$ ratios were not raised, indicating adequate peripheral oxygenation.

Several authors have investigated the response of the pancreatic endocrine cells in the perinatal period, both in the human and in animal studies in vivo and in vitro. The pancreatic- $\alpha$ and the $\beta$-cells in mature infants respond to amino acids during the first day of life (Fiser et al., 1975; Williams et al., 1975), but there appears to be a change in the pattern of the plasma insulin response to glucose during the first week of life (Falorni et al., 1974). Lowy and Schiff (1968) showed that feeding on the first day of life in man did not increase urinary excretion of insulin, while Asplund (1972) concluded that in rats postnatal feeding was necessary for the $\beta$-cell responses to mature. No previous study has reported the effect of a milk feed on plasma insulin on the first day of life. In our patients we found a definite plasma insulin response to the feed of breast milk. The delayed and small magnitude of the response may partly reflect the small rise in blood glucose, although it could also be a reflection of immaturity of $\beta$-cell responsiveness.

Insulin secretion can also be stimulated by several gut hormones (the 'entero-insular axis'), but little is known of gastrointestinal hormone function in the newborn. Recent work in mature neonates has shown that the plasma levels of gastrin, secretin, and enteroglucagon are higher on the fourth day of life than on the first (Rogers et al., 1974, 1975), suggesting that the gastrointestinal hormones themselves have an immaturity of response which takes some time to develop fully. However, we found a rise in plasma gastrin and enteroglucagon, although there was no change in plasma GIP. It is impossible to comment further on the significance of these changes since the physiological role of these hormones in the neonate has yet to be defined.

The basal pancreatic glucagon levels were similar to those previously reported in normal infants using the same assay (Bloom and Johnston, 1972) but no change occurred after the feed. Plasma growth hormone increased further after the feed from the high basal level. This rise could have been due to pituitary stimulation by the protein content of the feed or it may be a manifestation of the paradoxical rise associated with an increase in blood glucose concentration reported by others in this age group (Cornblath et al., 1965). Similar increments in growth hormone during the hyperglycaemic phase after feeding have been reported in young lambs (Bassett, 1974).

In these studies on sick infants the potentially important influence of sucking was excluded (Bassett, 1974). The results may not therefore be directly applicable to entirely normal infants. They do show, however, that the human newborn is able to respond to feeding immediately after birth, in that breast milk stimulates the secretion of several hormones and increases the circulating level of glucose. Further work is needed to follow the subsequent development of feeding responses during the first days of life.

We thank Professor J. P. M. Tizard for his advice and encouragement, the nursing staff of the Special Care Baby Unit for their help, and Mrs. E. Harris and Mrs. V. Ilic for skilled technical assistance. D. H. W. is a member of the MRC external staff.

\section{References}

Albano, J. D. M., Ekins, R. P., Maritz, G., and Turner, R. C. (1972). A sensitive and precise radioimmunoassay of serum insulin. Acta Endocrinologica, 70, 487-509.

Asplund, K. (1972). Effects of postnatal feeding on the functional maturation of pancreatic islet $\beta$-cells of neonatal rats. Diabetologia, 8, 153-159.

Bassett, J. (1974). Early changes in plasma insulin and growth hormone levels after feeding in lambs and adult sheep. Australian Journal of Biological Sciences, 27, 157-166.

Bergmeyer, H. (1963). (Editor.) Methoden der enzymatischen Analyse. Chemie, Weinheim.

Bloom, S. R. (1974). Hormones of the gastrointestinal tract. British Medical Bulletin, 30, 62-67.

Bloom, S. R., and Johnston, D. I. (1972). Failure of glucagon release in infants of diabetic mothers. British Medical Journal, 4, 453-454.

Cornblath, M., Parker, M. L., Reisner, S. H., Forbes, A. E., and Daughaday, W. H. (1965). Secretion and metabolism of growth hormone in premature and full term infants. Journal of Clinical Endocrinology and Metabolism, 25, 209-218.

Falorni, A., Fracassini, F., Massi-Benedetti, F., and Maffei, S. (1974). Glucose metabolism and insulin secretion in the newborn infant. Comparisons between the responses observed on the first and seventh day of life to intravenous and oral glucose tolerance tests. Diabetes, 23, 172-178.

Fiser, R. H., Williams, P. R., Fisher, D. A., DeLameter, P. V., Sperling, M. A., and Oh, W. (1975). The effect of oral alanine on blood glucose and glucagon in the human newborn infant. Pediatrics, 56, 78-81.

Gentz, J. C. H., Persson, B., Kellum, M., Bengtsson, G., and Thorell, J. (1971). Effect of feeding on intravenous glucose tolerance and insulin response in piglets during the first day of life. Life Sciences, 10, 137-144. 
Hey, E. N., and Katz, G. (1970). The optimum thermal environment for naked babies. Archives of Disease in Childhood, 45, 328-334.

Lowy, C., and Schiff, D. (1968). Urinary excretion of insulin in the healthy newborn. Lancet, 1, 225-227.

Rogers, I. M., Davidson, D. C., Lawrence, J., Ardill, J., and Buchanan, K. D. (1974). Neonatal secretion of gastrin and glucagon. Archives of Disease in Childhood, 49, 796-801.

Rogers, I. M., Davidson, D. C., Lawrence, J., and Buchanan, K. D. (1975). Neonatal secretion of secretin. Archives of Disease in Childhood, 50, 120-122.

Shelley, J. H., Bassett, J. M., and Milner, R. D. G. (1975). Control of carbohydrate metabolism in the fetus and newborn. British Medical Bulletin, 31, 37-43.
Turner, R. C., Schneeloch, B., and Paterson, P. (1971). Changes in plasma growth hormone and insulin of the human foetus following hysterotomy. Acta Endocrinologica, $66,577-586$.

Williams, P. R., Fiser, R. H., Sperling, M. A., and Oh, W. (1975). Effects of oral alanine feeding on blood glucose, plasma glucagon and insulin concentrations in small-forgestational-age infants. New England Journal of Medicine, 292, 612-614

Correspondence to Dr A. Aynsley-Green, University Department of Paediatrics, John Radcliffe Hospital, Oxford OX3 9DU. 